cal interrelation, so, too, symposia and quaestiones were refitted and sent on their way, much improved by Plutarch's thoroughgoing overhaul. ${ }^{30}$

GEORGE W. M. HARRISON

Xavier University

30. This paper was first read at the 1996 Annual Meeting of the American Philological Association, which expanded upon remarks made at the Fifth Congress of the International Plutarch Society (Leuven, 1996). The author is grateful to everyone who made comments and suggestions at these two fora, and also to the referees for this journal.

\title{
AUSONIUS' JUVENAL AND THE WINSTEDT FRAGMENT
}

A century ago the Oxford undergraduate E. O. Winstedt discovered in a late eleventh/early twelfth-century Beneventan manuscript (Bodleian MS Canon. Class. 41; $\mathbf{O}$ for Oxoniensis) thirty-four previously unknown lines embedded in Juvenal's sixth Satire. ${ }^{1}$ The authenticity ${ }^{2}$ of the unique lines and their nearly total lapse from the tradition, if they are genuine ${ }^{3}$ remain subjects of dispute. This study presents new evidence for the lines' antiquity, if not genuineness. ${ }^{4}$ I argue that Decimus Magnus Ausonius, the scholar and poet of fourth-century Bordeaux, alludes in a single poem to Juvenal's sixth satire as a whole and especially to the Winstedt lines. From this I propose that he knew the Winstedt lines and knew them as belonging to Satire 6 .

1. E. O. Winstedt, "A Bodleian MS of Juvenal," $C R 13$ (1899): 201-5. Citations from Juvenal follow the second edition of W. V. Clausen's OCT (Oxford, 1992). For the Oxoniensis see E. A. Lowe, The Beneventan Script (Oxford, 1914), 17, 190, 195, 212, 291, 293, with second ed. prepared and enlarged by V. Brown (Rome, 1980), II 110; J. G. Griffith, "The Survival of the Longer of the So-Called 'Oxford' Fragments of Juvenal's Sixth Satire," Hermes 91 (1963): 104-14, esp.105; R. Tarrant, "Juvenal," in Texts and Transmission, ed. L. D. Reynolds (Oxford, 1983), p. 202, n. 22; F. Newton, The Scriptorium and Library at Monte Cassino 1058-1105 (Cambridge, 1999), index of MSs.

2. Against genuineness: F. Bücheler, "Der echte oder der unechte Juvenal," RhM 54 (1899): 484-88; U. Knoche, "Ein Wort zur Echtheitskritik," Philologus 93 (1938): 196-217 (cf. Griffith, "'Oxford' Fragments," p. 109, n. 1); idem, "Handschriftliche Grundlagen des Juvenaltextes," Philologus 33.1 (Berlin, 1940), 54, 71; B. Axelson, "A Problem of Genuineness in Juvenal," in $\Delta \rho \dot{\alpha} \gamma \mu \alpha$ M. P. Nilsson (Lund, 1939), 40-55; W. S. Anderson, "Juvenal 6: A Problem in Structure," CP (1956): 73-94; M. D. Reeve, "Gladiators in Juvenal's Sixth Satire," CR 23 (1973): 124-25; J. A. Willis, "Juvenalis male auctus," Mnemosyne 42 (1989): 441-68. In defense of genuineness: J. P. Postgate, "On the New Fragments of Juvenal," CR 13 (1899): 2068; A. E. Housman, "The New Fragment of Juvenal," $C R 13$ (1899): 266-67; idem, "The New Fragment of Juvenal," $C R 15$ (1901): 263-66; idem, "Tunica retiarii," CR 18 (1904): 395-98; R. Ellis, The New Fragments of Juvenal: A Lecture Delivered at Corpus Christi College on Tuesday, February 5, 1901 (Oxford, 1901); H. L. Wilson, "The Bodleian Fragments of Juvenal," AJP 22 (1901): 268-82; E. Courtney, "Vivat ludatque cinaedus," Mnemosyne 15 (1962): 262-66; idem, A Commentary on the "Satires" of Juvenal (London, 1980), 304-9; G. Laudizi, Il frammento Winstedt (Lecce, 1982); G. Mohilla, Juvenals Oxford-Verse O 1-34: Neue Interpretation im Rahmen von Studien zur Kompositionstechnik seiner Satiren (Ph.D. diss., Vienna, 1990), unavailable for autopsy; see summary in Sprachkunst 22 (1991): 133.

3. F. Nougaret, "Juvénal, Omission du fragment Winstedt," in Mélanges E. Chatelain (Paris, 1910), 255-67; L. Herrmann, "Sur la disposition de l'original de Juvénal," Latomus 11 (1952): 334-36; R. Verdière, "Juvenalianum," Latomus 11 (1952): 25-26; E. Courtney, "The Transmission of Juvenal's Text," BICS 14 (1967): 38-50, esp. 38-39; idem, "Vivat," 302, 304. G. Luck, "The Textual History of Juvenal and the Oxford Lines," HSPh 76 (1972): 217-32, 218, 223, 231, is less credible; for other attempts to place the fragment after line 345, see S. G. Owen, "The New Fragment of Juvenal," $C R 13$ (1899): 267; Griffith, “'Oxford' Fragments," 111-13.

4. J. A. Willis, in his 1997 edition (Teubner), rejects the lines, without comment; cf. his earlier ("Juvenalis") effusive comments. 
In a short poem commemorating his deceased sister Julia Dryadia, Ausonius alludes in general to Satire 6 and in particular to the eighteenth Winstedt line. ${ }^{5}$ The allusive program is delicate and complex, flagged by a nearly verbatim lexical echo in identical metrical position. The echo is framed by a pair of additional echoes and embedded in a matrix of more thematic and generic allusions. The resulting nexus serves both to interpret the poem to which Ausonius alludes and to invite interpretation of the Ausonian poem itself. ${ }^{6}$ The allusive program relies on the entire thematic and generic context of the poem to which Ausonius alludes and that of the poem in which the allusion is drawn (Parentalia [10] 12): ${ }^{7}$

Si qua fuit virtus, cuperet quam femina prudens esse suam, soror hac Dryadia haud caruit;

quin etiam multas habuit, quas sexus habere fortior optaret nobilitasque virum;

docta satis vitamque colo famamque tueri, docta bonos mores ipsa suosque docens;

et verum vita cui carius, unaque cura nosse deum et fratrem diligere ante alios.

coniuge adhuc iuvenis caruit, sed seria vitam moribus austeras aequiperavit anus.

produxit celerem per sena decennia vitam inque domo ac tecto, quo pater, oppetiit.

The Winstedt fragment reads $(6.0 .1-34):^{8}$

in quacumque domo vivit luditque professus obscenum et tremula promittens omnia dextra, invenies omnis turpes similesque cinaedis. his violare cibos sacraeque adsistere mensae permittunt, et vasa iubent frangenda lavari

cum colocyntha bibit vel cum barbata chelidon. purior ergo tuis laribus meliorque lanista, in cuius numero longe migrare iubetur psyllus ab †eupholio. $†$ quid quod nec retia turpi iunguntur tunicae, nec cella ponit eadem munimenta umeri $\nmid$ pulsatamque arma $\nmid$ tridentem qui nudus pugnare solet? pars ultima ludi accipit has animas aliusque in carcere nervos. sed tibi communem calicem facit uxor et illis cum quibus Albanum Surrentinumque recuset

flava ruinosi lupa degustare sepulchri.

horum consiliis nubunt subitaeque recedunt,

his languentem animum $\dagger$ servant $\dagger$ et seria vitae,

5. First noted by R. P. H. Green, "Ausonius' Use of the Classical Latin Poets: Some New Examples and Observations," CQ 27 (1977): 441-52, esp. 445.

6. See J. D. Sosin, “Ausonian Allusions to Juvenal's Satires," WS 114 (1999): 91-112.

7. Citations from Ausonius follow R. P. H. Green, ed., The Works of Ausonius (Oxford, 1991).

8. Serious textual problems in the Winstedt fragment remain; see Housman, "Tunica," 395-98; Reeve, "Gladiators," 124-25; P. T. Eden, "Juvenaliana," Mnemosyne 38 (1985): 334-52, esp. 338-40; R. G. M. Nisbet, "Notes on the Text and Interpretation of Juvenal," in Vir bonus discendi peritus: Studies in Celebration of Otto Skutsch's Eightieth Birthday, ed. N. Horsfall (London, 1988), 86-110, esp. 97; S. M. Cerutti and L. Richardson Jr, "The retiarius tunicatus of Suetonius, Juvenal, and Petronius," AJP 110 (1989): 589-94. 
his clunem atque latus discunt vibrare magistris, quicquid praeterea scit qui docet. haud tamen illi semper habenda fides: oculos fuligine pascit distinctus croceis et reticulatus adulter. suspectus tibi sit, quanto vox mollior et quo saepius in teneris haerebit dextera lumbis. hic erit in lecto fortissimus; exuit illic personam docili Thais saltata Triphallo. quem rides? aliis hunc mimum! sponsio fiat: purum te contendo virum. contendo: fateris? an vocat ancillas tortoris pergula? novi consilia et veteres quaecumque monetis amici, 'pone seram, cohibe.' sed quis custodiet ipsos custodes, qui nunc lascivae furta puellae hac mercede silent? crimen commune tacetur. prospicit hoc prudens et ab illis incipit uxor.

R. P. H. Green (“Ausonius' Use" [n. 5 above]) saw the echo seria vitam (Parentalia [10] 12.9) for seria vitae (Juv 6.0.18) more than twenty years ago, but neither then nor in his 1991 edition of Ausonius did he comment on its implications for the text of Juvenal; nor has anyone else. ${ }^{9}$ The allusion is embedded in a cluster of less direct allusions. By privileged tricolon Ausonius stresses that Julia Dryadia was both well educated and a good educator (5-6): docta satis vitamque colo famamque tueri, I docta bonos mores ipsa suosque docens. The repetition is forceful. Dryadia plays a vital role in the transmission of the mos maiorum; she both learns it well and teaches it well. The male role models in her life take part in this process: brother, husband, and father.

Dryadia's lessons contrast sharply those learned by the adulterous wife from the interloper cinaedi of Satire 6, yet the emphasis on paideia, a persistent theme in Satire 6, is the same: consiliis (17), discunt (19), magistris (19), docet (20). Dryadia knew just enough (docta satis, 5) to remain chaste and reputable, but Juvenal's woman desires to appear excessively learned and witty (nam quae docta nimis cupit et facunda videri...6.445). ${ }^{10}$ Elsewhere in the satire the rustic and attentive Thymele learns from the moans of women in climax at the theater (attendit Thymele: Thymele tunc rustica discit, 6.66). A mother-in-law teaches her daughter to "rejoice in the spoils of her stripped husband" (illa docet spoliis nudi gaudere mariti, 6.232), and to send secret love letters (illa docet missis a corruptore tabellis / nil rude nec

9. Perhaps Green did not discuss the allusion to $\mathbf{O} .18$ because he thought it an unconscious by-product of Ausonius' expansive reading. But conscious or not, the allusion opens a window on the text of Juvenal's Satires. As we shall see, the complexity of Ausonius' program of allusion, of which the allusion to $\mathbf{0 . 1 8}$ is but one part, suggests that the echo was no accident. In dismissing "Peiper's grotesque conjecture vitans in 9,” D. R. Shackleton Bailey, “Ausoniana," AJP 97 (1976): 249, would emend vitam to vitae - without noting that the emendation makes Ausonius' two words a quotation (morphologically, not syntactically) of Juvenal. M. Lolli, ed., D. M. Ausonius, "Parentalia" (Brussels, 1997), follows Peiper (p. 150): "Insomma, la sorella seppe attenersi ai rigidi costumi tipici della vecchiaia, pur evitandone l'eccessiva gravità." The point, however, is that to the approval of Ausonius she did adopt the stern behavior of older women; Dryadia resisted remarrying in spite of the fact that her youth might have made it socially more acceptable. The collocation does not occur elsewhere before Ausonius. Bede Hymni Tredecim 2 (PL 94 col. 607 D [Migne]), Talibus ergo modis animarum commoda primum / Quaerantur post haec praesentis seria vitae, is later in date and lacks the support of context to suggest influence.

10. Where nimis goes equally well with docta or cupit. 
simplex rescribere, 6.233-34). In fact, says Juvenal, the mother-in-law is capable of teaching only disgraceful habits, since she herself inherited them from her mother (scilicet expectas ut tradat mater honestos / atque alios mores quam quos habet? 239-40). Juvenal opens the book with this theme, tracing immorality's transmission to the period after Pudicitia's departure from earth (6.1-2), when men were made of clay and had no parents to teach them bad ways (6.13). Juvenal's adulteress is as closely tied to a legacy of learned debauchery as Dryadia is to learned chastity. Like elegy's docta puella, Juvenal's woman is educated in the art of deception, whereas Dryadia's paideia is in traditional morality. Juvenal's woman learns the very things that Dryadia learned not to do.

Line after line Ausonius' poem answers Juvenal's. While Dryadia associates with the men in her own household, the woman in Satire 6 falls willing prey to the cinaedus (23-25), an effeminate outsider. Juvenal's adulteresses flit from husband to husband in the Winstedt fragment (17) and elsewhere in Satire 6 (229-30), abandoning severity in their lives (18). ${ }^{11}$ Dryadia, by contrast, loses her husband at a young age and never remarries (9-10), adopting instead a stern severity in her life (9). In both poems the idea of the loss of a husband (through death or divorce) is intimately linked to the two echoed words. Dryadia learns to manipulate the distaff (5), the time-tested emblem of a Roman noblewoman's chastity; the adulteresses learn less chaste maneuvers (19-20). Dryadia learns the habits of good people (6), unlike the woman in Satire 6 who learns from effeminate cinaedi. Dryadia holds truth dear (7); the cinaedi who instruct Juvenal's adulteresses hold it in contempt (20-21). Dryadia is so virtuous that she transcends the limits of her gender (3-4). The cinaedi are so debauched that they sink beneath the expectations of theirs (23-26). Dryadia lives and dies at home (12), and unlike Juvenal's woman (31), requires no lock and key to stay put. The woman of Satire 6 remains only in the house where the cinaedus conducts lessons (1-2). Dryadia and the woman in Satire 6 are both discreet ( prudens), but the femina prudens (1), Dryadia, is intent on virtus (1) and Juvenal's uxor prudens (34) is intent on crimen (33).

Ausonius, however, is not content to build his case on commonplaces. With these last two parallels the full structure of the allusion emerges. Ausonius draws an overt, structural parallel between Parentalia [10] 12 and the Winstedt fragment: direct chiastic correspondence between the first and last lines of the two passages. Half of the allusive frame describes Dryadia as prudens in the maintenance of her virtue; Juvenal's woman, by contrast, is prudens in her secret evasion of the guards posted to safeguard her virtue:

Ausonius Parentalia [10] 12.1 Si qua fuit virtus, cuperet quam femina prudens Juvenal Satires 6.0.34 prospicit hoc prudens et ab illis incipit uxor.

The other half of the frame depicts Dryadia as she nobly dies in her own home, while Juvenal's woman leads a debauched life in any home in which the cinaedus holds lessons:

11. The crux $\dagger$ servant $\dagger$ persists: Housman, "New Fragment," 266. Housman and Postgate must have been correct to conjecture solvunt, relevant (A. E. Housman, D. Iunii Iuvenalis "Saturae," $2 \mathrm{~d}$ ed. [Cambridge, 1931]); Ausonius attributes to his sister the opposite of the ways of Juvenal's women. Eden's clever conjecture ("Juvenaliana," 340) versant ad seria vitae does not seem to fit the sense. 
Ausonius Parentalia [10] 12.12 inque domo ac tecto, quo pater, oppetiit.

Juvenal Satires 6.0.1 in quacumque domo vivit luditque professus

The two phrases, inque domo ac tecto and in quacumque domo, share meaning and meter, both filling the first two and one-half feet of their lines. ${ }^{12}$ The potent concepts of prudentia and the domus, the proper setting for a woman to demonstrate prudentia, frame Ausonius' poem and the Winstedt fragment. The thematic echoes are thickest in the middle of both, surrounding the overt lexical echo and the mention of loss or abandonment of a husband, to which it is so intimately linked in both passages. Thus the substructure of the allusion is anchored at the beginning, middle, and end of both passages.

On this substructure Ausonius builds his program of thematic allusion. Both poems treat the theme of the limitations and expectations of the female sexus (Parentalia [10] 12. 3). In his surviving verses Juvenal employs the word sexus only five times (excluding the spurious 11.169). It appears first in the female interlocutor's interjection at 2.47-48, in which she tells the acts to which her sexus will not stoop. The other four occurrences are found in Satire 6. In all four cases, as in Ausonius' use, the word describes what the narrator considers normative activity on the part of women $(6.134-35,252-53,340-41,646-48)$. In the two most striking passages, the first and last, women are depicted as predisposed to vice by their sexus: faciunt graviora coactae / imperio sexus minimumque libidine peccant (6.134-35); minor admiratio summis / debetur monstris, quotiens facit ira nocentes / hunc sexum ... (6.646-48).

On Juvenal's conception of the female sexus, women seem naturally to be prone to lapses of virtue. But Ausonius boasts that Dryadia transcended through traditional moral paideia the putative limitations of her sexus so that men would emulate her virtue. ${ }^{13}$ Juvenal's sixth satire offers one of Latin poetry's richest commentaries on the female sexus and so makes an excellent foil for Ausonius' portrayal of Dryadia's transcendence of gender. Ausonius builds and buttresses his theme against an opposing formulation from Juvenal's Satires. Ausonius' portrait of the chaste and dutiful Dryadia derives poignancy from its inversion of Juvenal's picture of women in Satire 6. In so defining allusively the theme of his own poem Ausonius adopts a moralizing interpretation of the Winstedt lines and Satire 6 and lays foundations for interpreting his own poem.

The nexus of lexical and thematic allusion further evokes a generic tension between the two poems. The Parentalia, a series of poems honoring dead relatives, does not fall within an easily identifiable genre. The individual poems, though typically short, are not epitaphs; nor are they quite epicedia. ${ }^{14}$ Ausonius offers the following apology for the generic outlier (Parentalia [10] Preface 4-9):

12. Just as Ausonius inverts the Juvenalian picture, his first half-line (- $-|--|-\|)$ is metrically the mirror-image of Juvenal's penultimate $(--|-\cup-|-||)$.

13. For a similar description of his maternal aunt who died a virgin see Parentalia [10] 6.7-8: feminei sexus odium tibi semper, et inde / crevit devotae virginitatis amor. Ausonius uses the word sexus on only four other occasions: Professores (11) 3.6, Epigrammata (13) 111.3, Cupido cruciatus (19) verse 19, Technopaegnion (25) 7.2 .

14. Green, Works of Ausonius, 299-300, suggests, "their closest affinities are with the more polished kinds of sepulchral epitaph and funerary poems of Martial, but the idea of a sequence is almost certainly Ausonius' own." 
hoc opusculum nec materia amoenum est nec appellatione iucundum. habet maestam religionem, qua carorum meorum obitus tristi affectione commemoro. titulus libelli est Parentalia. antiquae appellationis hic dies et iam inde ab Numa cognatorum inferiis institutus: nec quicquam sanctius habet reverentia superstitum quam ut amissos venerabiliter recordetur.

If a formal generic label is not obvious, the tone of the work is. The solemn piety of the Parentalia is signaled by the words religionem, commemoro, antiquae, inferiis, sanctius, reverentia, venerabiliter. ${ }^{15}$ The title itself harks back to the earliest days of Rome and to Numa, the father of Roman religion. Ausonius stresses that in spite of the book's brevity (opusculum, libelli) and its invocation of Roman pastoral piety, it forsakes the light-hearted sweetness of which pastoral is capable (nec . . amoenum, nec... iucundum). These dedications are written in a minor key; note the striking collocations maestam religionem and tristi affectione. This quiet solemnity marks the poem dedicated to Julia Dryadia. Like the archetypal Roman matron Lucretia, Dryadia scrupulously protects her good name (famam, 5) with her spinning (colo, 5). She has learned respect for the mos maiorum (bonos mores, 6 ). She is devoted to the men in her life (fratrem, 8; coniuge, 9) and to god (deum, 8). The sober language and sentiment stand against the debauched world on display in Satire 6 in general and the Winstedt fragment in particular.

Moreover, if the powerful invocation of Juvenal were insufficient to mark Ausonius' refutation of satire's portrait of woman, Ausonius signals in another place the friction between his poem and satire. Dryadia is said to have been docta satis vitamque colo famamque tueri (5). The phrase invokes a passage from Horace's defense of satire in which he reports a chapter from his own paideia: his father's advice (105) on avoiding Juvenal-style adultery $(1.4 .111-20) .{ }^{16}$

\begin{tabular}{ll}
\multicolumn{2}{c}{ a turpi meretricis amore } \\
cum deterreret, "Scetani dissimilis sis." \\
ne sequerer moechas, concessa cum venere uti \\
possem, "deprensi non bella est fama Treboni," \\
aiebat. "sapiens, vitatu quidque petitu \\
sit melius, causas reddet tibi; mi satis est, si \\
traditum ab antiquis morem servare tuamque, \\
dum custodis eges, vitam famamque tueri \\
incolumem possum; simul ac duraverit aetas \\
membra animumque tuum, nabis sine cortice." sic me & 120 \\
formabat puerum dictis. &
\end{tabular}

The connection between Horace's and Ausonius' descriptions of the transmission of morality down the family tree and within the home is plain. But by grafting the Horatian echo to the tissue of the Juvenalian allusion Ausonius creates a relationship between the two passages from satire that otherwise might not have been obvious. Juvenal and Horace portray flipsides of the same coin: satire's moral paideia. Ausonius' allusion to the Winstedt fragment focuses on the theme of teaching and learning morality and immorality. Ausonius appropriates the passage from Horace to

15. Lolli, "Parentalia," 25-31, 29, 48.

16. Lolli, "Parentalia," 149, cites the parallel without comment. 
fortify his own poem's function as a corrective to the Juvenalian picture. Dryadia upheld the mos maiorum (6) and guarded her own "life and reputation" (5); the young Horace was on the right track, but still required a custos (118) to help him protect the mos maiorum (117) and guard his "life and reputation" (118)—only until maturity could toughen his body and mind (119-20). By contrast Juvenal's promiscuous woman had no respect for life (18) and reputation; her body and mind were wanton and seductive (18-19); and custodes (31-34) were useless in enforcing the mores that Dryadia adopted on her own and Horace followed with gentle urging.

Ausonius' double allusion to Horace and Juvenal in this short poem has a sophisticated efficiency. ${ }^{17}$ Ausonius superimposes Horace's depiction of the dutiful son learning morality from his father at home on Juvenal's portrait of the reckless woman breaking out of her home in order to study immorality at the feet of debauched cinaedi. In the portrait of his sister learning morality at home, even transcending the limitations of her gender, and eventually dying in the same home as her father, Ausonius musters additional moral strength from the Horatian "type" and Juvenalian "anti-type," which share a common context only (or especially) insofar as Ausonius' double allusion provides one.

The allusions to Satire 6 and the Winstedt fragment are complex and systemic. A lexical echo is framed by a pair of additional echoes and embedded in a matrix of generalizing allusion. On this substructure Ausonius builds his theme, which stands resolutely against Juvenal's. This thematic point and counterpoint accompanies a generic tension that is signaled by the allusion to Horace's programmatic Sermo 1.4, and enriched by Ausonius' claim of opposition to one satiric voice and allegiance to another. Ausonius capitalizes on this nexus of multiple lexical allusion, thematic opposition, and generic tension to mount a poetic refutation of Juvenal's sixth satire, both interpreting the echoed text and providing a mode of interpretation for his own poem.

Ausonius' allusion to the Winstedt fragment proves his acquaintance with it. Moreover, by isolating themes of learning morality and immorality, the sanctity or debasement of marriage, prudentia used for both virtus and crimen, the inviolability of the domus, and the limitations and expectations of the female sexus, all of which figure prominently not only in the Winstedt fragment but in Satire 6 as a whole, Ausonius treats the Winstedt lines as an integral and functioning part of the sixth satire. That Ausonius' allusive agenda pursues this opposition in nearly every one of his poem's 12 lines is, I suggest, compelling evidence that he knew the Winstedt fragment from a manuscript that contained the lines somewhere in Satire $6 .^{18}$

Ausonius stood at the head of a long line of late Latin poets and historians with a keen interest in Juvenal and was already integrating the Satires with his own poetry by the early 370 s. Juvenal was the object of scorn in a famous passage of Ammianus Marcellinus (28.4.14), who in spite of his spirited condemnation borrowed numerous phrases from the poisonous poet. ${ }^{19}$ In addition he was carefully read and mined by

17. For this strategy in Ausonius see Sosin, "Ausonian Allusions," 98-104 and esp. 104-10.

18. This copy may have been in his hands by ca. $377 / 8$ when he began composing the Parentalia (Green, Works of Ausonius, 298). Ausonius' treatment of the lines as a unity does not suggest that he knew the fragment as an independent poem. The latter half of the sixth satire consists of a series vignettes: e.g., 366-78, 379-97, 398-412, 413-33, 434-56, 457-73; see Courtney, "Vivat," 256-58.

19. E. Courtney, “A Miscellany on Latin Poetry,” BICS 29 (1982): 49-54, esp. 53. 
Prudentius, ${ }^{20}$ Claudian, ${ }^{21}$ the Scriptores Historiae Augustae, ${ }^{22}$ Ausonius' own student Paulinus of $\mathrm{Nola}^{23}$ and Servius, ${ }^{24}$ none of whom shows knowledge of the Winstedt fragment. How Ausonius knew such a rare and special manuscript is beyond our grasp. Nevertheless, it is worth speculating that just as Ausonius the poet had an obvious interest in the recently fashionable Satires-claims to be on the cutting edge were and still are an integral component of poetic composition-Ausonius the scholar may have had a similar interest in obtaining exceptional manuscripts of the Satires.

Ausonius' acquaintance with the Winstedt lines as belonging to Juvenal Satire 6 is not proof positive of Juvenalian authorship. It is, however, compelling that Ausonius, a scholar and poet separated from Juvenal by no more than 250 years, alludes to the lines as an integral part of Satire 6. The brief glimpse of Ausonius' Juvenal provides unparalleled evidence for the transmission of the Satires and the Winstedt fragment and suggests that, while some scholars question the genuineness of the lines today, Ausonius himself had no doubts. ${ }^{25}$

\section{Joshua D. Sosin \\ Massachusetts Institute of Technology}

20. G. Highet, Juvenal the Satirist (Oxford, 1954), p. 298, n. 10; E. B. Lease, Syntactic, Stylistic, and Metrical Study of Prudentius (Ph.D. diss., Baltimore, 1895), 71-72; G. B. A. Fletcher, "Juvenaliana," Latomus 35 (1976): 108-16, esp. 111; add Prudent. C. Symm. $2.585 \approx$ Juv. 10.17.

21. Highet, Juvenal, p. 301, n. 22; A. Cameron, "Notes on Claudian's Invectives," CQ 18 (1968): $387-$ 411 ; idem, Claudian: Poetry and Propaganda at the Court of Honorius (Oxford, 1970), index s.v. "Juvenal"; Fletcher, Study of Prudentius, 112, 113, 116.

22. A. Cameron, "Literary Allusions in the Historia Augusta," Hermes 92 (1964): 369-71; B. Baldwin, "Juvenal and the Historia Augusta: Two Possible Concordances," AClass 33 (1990): 108-11; J. Schwarz, "L'Histoire Auguste, Suétone et Juvénal," in Romanitas-Christianitas: Untersuchungen zur Geschichte und Literatur der römischen Kaiserzeit, ed. G. Wirth et al. (Berlin, 1982), 634-44; Courtney, "Latin Poetry," $52-53$.

23. Highet, Juvenal, p. 184, p. 298, n. 9; R. P. H. Green, The Poetry of Paulinus of Nola: A Study of His Latinity (Brussells, 1971), 17, 49, 53, 62-63.

24. J. Fendrick, Servius' Knowledge of Juvenal: An Analysis of the Juvenalian Quotations in Servius' Commentary on Vergil (Ph.D. diss., U. Southern California, 1971); Servius was once credited with Juvenal's fourth-century renaissance; see P. Wessner, "Lucan, Statius und Juvenal bei den römischen Grammatikern," PhilWoch 10 (1929): 296-303, and 11 (1929): 328-35; A. Cameron, "The Date and Identity of Macrobius," JRS 56 (1966): 25-38, esp. 29-32, overturned this notion.

25. I am grateful to Kent Rigsby, Craig Gibson, and especially Francis Newton for thoughtful criticism. 